\title{
The Problematics of the Islamic Political Arab Identity: The Absence of Ummah in the Fiction of Munis Arazzaz
}

\author{
Ahmad Mohd Alkouri \\ School of Language Studies and Linguistics \\ Universiti Kebangsaan Malaysia \\ Raihanah M.M. \\ School of Language Studies and Linguistics \\ Universiti Kebangsaan Malaysia \\ Ruzy Suliza Hashim \\ School of Language Studies and Linguistics \\ Universiti Kebangsaan Malaysia
}

\begin{abstract}
This paper explores the problematic of Arab identity based on the absence of the notion of Ummah as represented in the fiction of Jordanian writer Munis Arazzaz. An analytical exploration of the novels of Munis Arazzaz namely, Alive In The Dead Sea (1982), Confessions Of Silencer (1986) and The Maze Of Bedouins In The Mirage Scrappers (1986) focuses on the protagonists' struggle to reunite the Arabs through a shared sense of national identity. The collective personal journey of the three protagonists, as this paper demonstrates, also parallels the journey of the Arab nation as it struggles to accomplish the mission of Arab unity. Arazzaz, as we problematise, depicts the tension between the Arab nation and the political leaders as a conflict between religious and political attachments. Collectively, the narratives illustrate two significant observations, which appear to foreshadow the current crisis in the Arab world. The first is the Arab nation's scuffle with its violent autocratic authorities, and the second is the intrusive political strategies used by the State to assert its political identity. These two-pronged conflicts reveal the main argument about the Arab identity crisis today pointing out the absence of the Islamic identity or the sorely missing notion of Ummah. The conclusion drawn from the explication of the narrative indicates that the assertion of political identity contradicts with the propagation of the Ummatic identity. The collective Muslim identity, or the Ummah, appears to be in decline and the crisis continues to linger, causing fragmentation and bitterness as seen in fiction and reality.
\end{abstract}

Key Words: Munis Arazzaz, Arab Identity, Ummatic Paradigm, Alive In The Dead Sea, Confessions Of Silencer, The Maze Of Bedouins In The Mirage Scrappers

\section{INTRODUCTION}

This paper explores the problematic of Arab identity based on the absence of the notion of Ummah as represented in the fiction of Jordanian writer Munis Arazzaz. An analytical exploration of the novels of Munis Arazzaz's, namely Alive In The Dead Sea (1982), Confessions Of Silencer (1986) and The Maze Of Bedouins In The Mirage Scrappers (1986) focuses on the protagonists' struggle to reunite the Arabs through a shared sense of national identity. Using an Islamic lens, the discussion into Arazzaz's representation of the Arab identity crisis can be examined from two main themes, leadership in Islam and ummatic paradigm. To what extent 
are these themes evident in the fiction of Arazzaz? What do these works of fiction reveal about the Arab identity crisis? These issues will form the core of this paper.

\section{The Islamic Perspective to Identity: Notion of Ummah and leadership}

A variety of definitions for the term Ummah have been suggested by scholars of Islam. The term Ummah generally means 'community'. It is associated with the term Umm, 'mother' or 'source'. The word Ummah is mentioned 64 times in the Quran. Khalil (1992: 177) literally explains the Ummah as "a group of living beings having certain characteristics or circumstances in common". According to the Quran, we are all created from a single source (umm): Adam and Eve. Humanity started out as a single community because its members followed the guidance of Allah, "and know that all mankind were once but one single community, ummatun wahidatun, and later did they begin to hold divergent views" (Al- Quran 10:19).

Al-Ahsan (1993: 18) further explains that an Ummah is a community based on a set of beliefs, and the Muslim Ummah believes in the guidance of One Allah (S.W.T) and in the prophethood of Muhammad (peace and blessing be upon him). Therefore, Ummah is not confined to the Arabs alone; its message is universal. It is addressed to the whole mankind (nas) as mentioned in the following verse: "Unto every one of you (mankind) have appointed a law and way of life (Shir'atan Wa Minhajan)" (Al- Quran 5:48). Additionally, Ummah is also used to describe a group of people who are committed to the beliefs of the whole community (qawm) as stated in verse (Al- Quran 7: 160). Ummah refers to the people within the community who enjoy divine guidance. Al-Ahsan (1993: 17) writes that "the Muslim Ummah provides the followers of Muhammad with a physical identity. More precisely Ummah is a community of law and customs". Historically, the Muslim power or the Ummah was so strong and had expanded to the whole world up until the Ottoman Empire. The power of the Muslim Ummah is due to the "unity amongst them" (Al-Ahsan 1993: 23). The Qur'an always asks the Muslim Ummah to be one and united. Moreover, there is no difference between them. The differences that parochialism brings in any nation like the loyalty to tribe, family, land and to others who share the same language or political affiliation, do not existed in Islam and are not applied in Muslim Ummah.

Furthermore, the Ummah is "based on the twin concept of brotherhood and equality" (Walt 1968: 97). Muslims are brothers to one another. They share their belief in tawhid (oneness of God), risalah (the message of Islam) and akhirah (believe in the hereafter). Both Quran and Sunah require Muslims to work together for the unity of Ummah. As a result, there is no room for nationalism in Islam. Islam is the religion not founded upon tribal or nation-state. In other words, the Muslims, whether they are of Chinese, African, European or Asian origin, are one Ummah and they cannot be separated from each other. The unity must never be broken by any tribalism as it is stated in the Quran, "The Faithful are but brothers..." (Al-Quran 49: 10). Therefore, the concept of Ummah is solid, rigid and persistent to all imported ideas or ties such as nationalism or tribalism.

Consequently, the concept of nationalism is totally unacceptable from the Islamic perspective. Ahmed and Abidkarim (1992:15) state, not only does Islam forbid people from honing on nationalistic ties, but "it also prohibits the establishment of more than one state, whether these states are based on nationalism or otherwise." The only government that is allowed for the Muslims is the Islamic governance, which is an authority for all Muslims that is governed exclusively by the tenets of Islam. Allah ( $\mathrm{s} w \mathrm{t}$ ) addressed the Messenger (peace and blessing be upon him), "And rule between them by that which Allah revealed to you, and do not follow their vain desires away from the truth which came to you" (Al-Quran 5: 48). The notion of 
Ummah, therefore, is a formation of identity for all Muslims at the present time as it was in the past. From this cornerstone, the following analysis will be considered as foundation to foreground the purpose of this paper. Within the various identities among Muslims and Arabs including the state identity, the Arab identity as the basis of national/ethnic identity is also examined in order to position what this paper terms as the misinformed and misguided Islamic identity.

\section{Leadership in Islam}

The only solution to remedy fragmentation and secularism in the current Muslim world is through Islamic leadership. Hasan (2010: 190) states that: "Unfortunately, many of the existing Muslim nation-states and the ruling political elites, decision-makers and leadership of Muslim countries do not portray the attributes of holistic excellence of the universal Ummah". The Muslim nation has been experiencing a schism due to strong leadership and more importantly, leadership that is governed by Shariah. This gap or gaps will be mentioned in the following paragraphs beginning with the importance of leadership in Islam.

Islam manages leadership based on certain conditions and rules. Leadership is considered as the actions of individuals who are chosen to be placed in position of authority, to oversee every aspect of societal wellbeing. Leadership position is active to the nation and hence should be held only by experienced capable people only. Therefore, the leader of Muslim community is called Caliph or Amir of Believers or ruler (el-Wali). This leader must be responsible for the people. On the other hand, the followers should obey the orders of their leaders. The Quran attests: "O ye who believers! Obey Allah, and obey the Messenger, and those charged with authority among you" (Al- Quran 5:59). However, people are expected to obey their leader's orders only if they are in line with God's orders.

The Islamic leader has the following qualities: charismatic: a "great man", a man with some sort of "miracle" to lead his followers to their ideals. A leader with real qualities according to the Islamic Shariah is beneficial to his nation. "The leader has a message: the loftiest of his duties is to develop leaders from among his people. He must be righteous as the nation depends on the righteousness of its Caliph. Then, the corruption of the nation is in his corruption" (Ikhlas \& Moudi 2001: 509). Therefore, the leader must be responsible. In this respect prophet Muhammad (peace and blessing be upon him) indicates that: "Every one of you is a custodian and responsible of his people". Many scholars such as Hawai (1982), Khadra (1985), Mostafa (1986) and Al-Obiedi (1987) have summarized the features of the Muslim leader. They assert that the Muslim leader must guarantee justice among his people. He should also apply the rules of Islamic law and preaches all the good. Besides, the Muslim leader must dissuade from evil and provide a decent livelihood for his people. He must be humble, forgiving, honest, honourable, patient, abiding by his promises, moderate, consultative, and respectable in appearance, and hold non-materialistic and ascetic values. These features are essential and assertive in any Muslim leader to be valid for the leadership.

In addition, at the core of the Islamic administrative theory, there lies a social philosophy of the Islamic system, which suggests that the individual's basic needs must be satisfied to achieve organisational goals and that a balance should be achieved between spiritual and psychological needs. The theory is based on the principles of hierarchical organisational structure, chain and unity of command, obedience and compliance to formal authority, planning of work, training, and development of employees (quoted in Ikhlas and Moudi 2001: 509) 
Abu Sin (1981) has tried to identify the postulates of Islamic administrative theory. The characteristics of the Islamic theory emphasizes on all the variables and factors that affect the administrative cycle in an organisation and its understanding of individual behaviour in light of social and cultural factors. The same is applied to the larger Islamic society of which administration is a subsystem. The basic postulates of Islamic theory can be summarized thus: firstly, Islamic administrative theory should be closely connected to the philosophy of the Islamic system and enforce the moral principle. Secondly, economic variables should also be taken into consideration in order to fulfill the individuals' physiological need. Thirdly, spiritual and psychological needs of the individual should be emphasized equally. Fourth and finally, it should pay attention to the organisation of work, organisational structure, relationship, and obedience to formal authority. According to Sharfuddin (1987: 231) there are some other variables to be taken into consideration in order to complete the paradigm of the Islamic theory. The first is the Shura which means the obligatory Matual Consultation and the "cardinal principle of the Islamic administrative system". Allah says in the holy Quran: "those who hearken to their lord, and establish regular prayers, and who conduct their affair by mutual consultation..." (Al-Quran 42: 38). The second element in the administrative system is the "Nasiha or Advice." It is an "inspirable factor in the effective functioning of any Islamic administrative system" (Sharfuddin 1987: 231). The prophet Muhammad (peace and blessings be upon him) said to his companions: "the religion is advice (Nasiha)" (Assalihin : 88). According to Sharfuddin (1987: 231) "in the early Islamic government, nasiha was given in all critical situations." Therefore, it is a need to include every aspect of life based on the teachings of Islam, as Islam is a complete way of life. Islamic identity will be handicapped, if Islamic economic, political, social and administration are absent in practice. As a leader of a nation, it is a must to enhance Islamic judicial, administrative system in order to uphold Islamic identity with the core value of justice and peace. Definitely, these principles could be the main key in Islamic system to achieve the Islamic identity. If the Islamic state or the leader of Islamic government applies these rules and principles, both individual and administration could reach satisfactory results. The following section sets out to investigate the extent Arazzaz has constructed these features of the Islamic leader in the authority figures of his novels.

\section{Analysis: Islamic Leadership in the Narration}

As stated earlier, leadership in Islam requires several conditions. The leader of Muslims is called a Caliph or Ameerul Mou'meneen or leader of the believers. In the novels, such titles is not being mentioned. In the first two novels, Alive In The Dead Sea and Confessions Of Silencer, the authority figures are both generals. The title 'General' indicates the head of an army. It also foreshadows a preparation for some form of altercation to come, leaving the readers with a sense of an impending crisis in leadership in the narrations.

To begin with, let us consider Arazzaz's first novel. Certain episodes in Alive In The Dead Sea, specifically the party scene reveals the truth about the authorities' uncertainty and loss of identity despite their positions as leaders of the Arab nation. The party in Arraed's house, inviting all VIP governments' and business' men who enjoy the wine food and dance, explains the imitation of the western lifestyle and declining the Islamic lifestyle. The scene shows that the authorities lack a strong sense of self-worth and self-respect as they allow themselves to indulge in their desires irrespective of the consequence. Fundamentally, they implement selfdriven agenda in governing the State, in contradiction to Islamic principles of the Ummah as philosophers such as Al-Farabi and Al-Mawardi to Alghazali and Ibn Khaldun state Islam, "have given so much significance to the role of the ruler in setting the moral tone and tenor of society" (Muzaffar 2011: 61). 
The behaviour of the authoritarians including Arraed in the night party episode shows all the anti-Arabism and anti-Islamism among the authoritarians. They are politicians but in fact they are not following the Islamic rules or principles. Although political issues look mysterious and unclear especially in the Arab politics, Horton \& Baumeister (1996: 5) have identified the political theory as "always been uncertain and shadowy" but with some "high level of generality". Therefore, common sense might be used as a generalisation of the Arab politics practiced today; that uncertainty in the Arab politics could be labeled as reasons to its crisis. A main contribution to the authoritarians' crisis in their policies and practices are the intact of secularism. Muzaffar (2011: 59) says that "most States established in the name of Islam, have failed miserably to uphold basic standards of public morality". Instead, secularism within its substantial meaning is unpredictable in its implementation by the Arab politics. The party as mentioned previously could explicate the implementation of the new State identity based on the State and the leaders' domination. Moreover, it is sad to witness that many of the Arab States use secularism as way of leading the country and that is one of the main causes in the Arabs' national fragmentation and lost identity.

Similarly, the novel Confessions Of Silencer indicates Arab corrupted authorities. Dr. Murad as an authoritarian and ideologist, who struggles for the Arab unity, becomes under house arrest by his companions in the same party. In fact, the political authority arrests Dr. Murad, one of attendee at the party, is equally unethical. The lack of morality in the second novel can be seen noticeably in two parts. The first is the torture on Dr. Murad during his house arrest and the assassination of his son Ahmad. The second part can be seen in the character of Yusuf, who was with Dr. Murad's party championing for the Arab unity, lately molded by the authority, and becomes their assassin. His lifestyle, through his confessions to the nightclub girl Silvia, and his job of killing people as ordered by the authority indicate the immorality of the Arab authorities. These two main sides of immorality in the novel reflect an extensive implementation of narcissism in ruling the nation, thus showcasing a lack of consideration for the Ummah among the Arab authorities.

Furthermore, the authority's treatment of the nationalists is inhuman and satanic despite the social and religious prohibition. They do not mind using any method, both legal and illegal, in achieving what they want. The authoritarian Arraed uses his power to threaten Enad, who is exiled from Jordan to assert the Arab unity, by saying: “I will arrest Mariam if Mahjoob doesn't surrender himself" (Alive 1982: 18). This threat is not only inhumane, it is also prohibited in Islam as no one should take responsibility or pay for another's mistake or fault. Still, the authority continues with its practice of aggression although it is against the Islamic rules and Shariah. This is sufficient proof of the Arab authoritarians' dictatorial attitude and their lack of Islamic conscience.

Another evidence of the secular Arab political system is seen in the excerpt of the killing of Muslim scholars. Arraed said to Enad mockingly that, "the only place for the Muslim Shehks in the dream State (Beirut) is hanging as death sentence" (Alive 1982: 13). The quote shows the anti-Islamic authoritarians' leadership as similar to the colonialists. Furthermore, in the unIslamic behaviour and disorder of Islam and Shariah, Arraed as a person of authority attacks all the Muslim religious figures and scholars by not even accepting them as members of the nation. The Arab authoritarians do not allow the Muslims to live freely and practice their religion. This fictive representation is a foreshadow of things to come as decades later the Arab nation collectively began an uprising which we now call the Arab spring, recording a clear evidence of conflict between the Brotherhood of Islamic Party and the government. Egypt until today considers the Muslim brotherhood as rebels. The authority's vision of Muslim scholars or 
Shikh explains their level of opposition and hatred towards Islam. Focusing on the scholars of Muslims means a direct attack against Islam as the religion of all Arabs. The Arab authorities show concern over the importance of restricting Muslims and driving them away from their religion, ultimately signaling their secularised mindset and subsequently crippling the nation. In a nutshell, the Arabs today can touch and feel the State of weakness and fragmentation.

In The Maze Of Bedouins In The Mirage Scrapper, the leadership has no representations and characters, yet the narration gives hints of the corrupted leadership. The oppression as mentioned above, which culminates to the point of assassinating people, is only for the sake of the authority. Fazza as a member in the Jordanian community wonders the sudden absence of people he knows and used to see them. The quote "Fazza is shocked of the missing of people, he named some such as: In Barakah and Imam,..." (The Maze 1986: 111) which refers to the murder of those who had gone missing, is a strong evidence of the genocide that took place authorized by the authorities.

In addition, the authorities always attack the opposition party, which, unfortunately, is the Islamic party. The brotherhood Muslim party is the example of main enemy for Arab authorities. They are called the opposition party in every country in the Arab nation. Mumtaz (2003: 387) states that: "The real obstacles towards Muslim unity are not external rather they are purely internal. They are related to Muslim culture and socio-political atmosphere of the Muslim world". As a result, the Muslims today live a huge crisis and are unable to lead themselves without secular interference. Secularised Arab governments and westernised Arab authorities have driven the Arab nation into an inferior position and subsequently have caused the downfall of the Ummah.

The fragmented Arab countries are based on the leaders' acceptance of the State system after the colonial era. In Alive In The Dead Sea, Arraed denies Enad's missions of revolution and ambition of Arab unity by asserting that the State priority comes first. He said to Enad: "With your crossed eyes, you can see the priorities of revolutions and don't realise the priorities of the State" (Alive 1982: 14). Arraed describes Enad with the metaphor of 'crossed eyes' to describe his ability to champion one cause instead of the other. Moreover, in Confessions Of Silencer, the authority arrested Dr. Murad and used surveillance tools to assert powerful control over the country as revealed by the detective: "I have installed all the hotels with these secretive CCTV with my hands" (Confessions 1986: 39). Therefore, the authoritarians' mission is accomplished only by using deceptive method irrespective of the human rights violations. As Muslim readers, the reading of these violations indicates the ultimate transgression by these figures of authorizes, as we are reminded in the Quran: "And rule between them by that which Allah revealed to you, and do not follow their vain desires away from the truth which came to you" (Al-Quran 5: 48).

\section{The Notion of Ummah in the Narration}

When a Muslim nation is ruled by un-Islamic authority or at least by an authority that does not practice and apply the Islamic rules and Shariah, the nation spirals into a sharp downfall. The nation struggles to gain its freedom against their rulers. Ignoring the Islamic rules in the State system is the main reason for the nation's crisis. Henceforth, the Muslims are asked to indoctrinate the Islamic rules based on loyalty to Allah.

The effect which the words 'nation' (Qawm) 'motherland' (Watan) has on the rest of the world is produced by the Muslims from the word 'God' or 'Islam'. You can stir the hearts of thousands in Europe simply with one word 'nation', but in the case of Muslims the only comparable word for this purpose is 'God' and 'Islam'. (Comments Azad during 1912. Quoted in Zeenath 1994: 1) 
However, when Muslims ignore the Islamic rules and practices, a huge crisis would occur in all aspects of their life as politically explained earlier, and socially is discussed in the followings.

In the fiction by Arazzaz, social illness, immorality and sins are implemented in the narratives to clarify the level of implementing Islam among Muslims. In the novel Confessions of Silencer, Yusuf asked Silvia to open the wine bottle for him to start his confession. "...and I looked at a dark corner...she agreed and we went there" (Confessions 1986: 54). Yusuf is a member in the intelligence department and also an assassin. His job does not allow him the privilege to indulge in personal needs and wants. Yet in this instance, Yusuf chooses to be intoxicated in order to relieve himself prior to his confessions.

Following this, Yusuf commits another sin, which is the adultery or zina. He looks at Silvia desirably. His lust immerses him overwhelmingly until he forgets about the sin of zina. "He gazes at her breast" and hopes that she is naked in front him. "She felt that and did go naked for him" (1992: 142). The situation shows the fulfilment of desires and ignorance of responsibilities to one's faith. From the Islamic perspective, a Muslim who commits this sin will experience a downfall, morally and socially, which subsequently weakness the Ummah.

Arazzaz problematizes how social illness, immorality and wrongdoings in a Muslim nation can cause the Muslim Ummah in his narratives. In Alive In The Dead Sea, Enad in the beginning of the novel was a "drunk and drug addict" (Alive 1982: 22). He spiraled into that state of frustration and depression after discovering the truth about the Lebanese authority, which crushed his last hope of achieving his dream. However, as a tragic end, Enad should have not drowned into the un-Islamic practices and behaviours. The narration exposes the trangressive practices of Muslims to uncover the weakest link in a Muslim nation. Similarly, the un-Islamic social aspects of the Arabs appear in Confessions Of Silencer, ironically, when Dr. Murad and his friends are portrayed to meet and discuss the issues of the Ummah issues in a bar that sells liquor. The narration indicates the beginning of un-Islamic behaviour amongst the leadership members to create an understanding of the exact position of Islam in the community and authority. Similarly, with the first and second novels, the ex-nationalist, Abu Toot, in The Maze Of Bedouins In The Mirage Scrappers, is a drunk who used to drink alcohol in a bottle of Pepsi (The Maze 1986 16, 46, 180). The Arab characters increasing transgressions and un-Islamic practices are evident the three novels. It is obvious to notice that, drugs, wine, smoking and other prohibited practices are becoming widely partly of the lifestyles of many urban Muslims. In that sense, one of the main predicaments of Muslims these days is due to the Muslims' lifestyle. When Muslims are away from religion and Shariah inevitable weakness and downfall will occur to them. "Muslims, more than perhaps most people, should be able to appreciate the importance of morality in public" (Muzaffar 2011: 59). Therefore, the Muslims' present day crisis is due to the negligence of Islam practice.

Another episode that illustrates the crisis can be seen when Enad desires to sleep with Arraed's wife Suzy. Although she is another Muslim's wife, he still has sexual desired towards her. Indeed, his attraction towards Suzy is a form of revenge against Arraed's manipulation of his dream of Arab Qawmeyya. Enad's lack of Islamic morality or Akhlaq allows him to ironically champion the cause of Arab unity while attempting to violate Suzy's person as a punishment for her husband's actions.

In addition, the scenes expose social problems of the Arabs in the narration. It could also be read as Arazzaz's cautionary commentary of the Arab crisis as they appear to be devoid of religious sensibilities. Furthermore, when a leader and symbol of the Ummah indulges in self- 
gratification it indicates the destruction of the Ummah. Thus the question readers are left with upon reading Arazzaz's narratives is this, how can the Ummah aspire for excellence when its leaders lack ethical and moral values? This is the main reason of the Ummah's crisis and downfall, the fragmented and weak leaders, whose secular mindset and practices, cripple the Ummah. Abdul Ghafur Muslim (2006: 1) said "The Ummah, the supra-national political community of Islam, established by Muhammad (peace and blessings be upon him), the Prophet of Islam, about fourteen hundred years ago, today consists of fifty-five sovereign States".

Therefore, the social illness infecting the Muslim societies generally and the Arab nation particularly, create a weak Muslim Ummah. In fact, "Islam tries to strike a balance between this world and the next and exhorts its followers to lead a moral life on earth and prepare for the other world through ibadaat (various spiritual acts of worship)" (Asghar Ali Engineer 2009: 110-111). The Quran, the main source of Islamic teachings, stresses piety (taqwa), cooperation in goodness (birr) and prohibits people from working with another in sin and aggression (AlQuran 5: 2). It is obvious from the verse of the Quran that governance is also dependent on the people's cooperation and the repudiation of sin and aggression. Aggression and violence upset the balance of life. The Quran also makes it the duty of every individual to enforce what is good (ma'ruf) and contain what is evil (munkar) (3: 110). Thus, people have to engage themselves continuously in promoting good and containing evil. This is the duty of every Muslim. Thus people are very much part of good governance. As Asghar Ali Engineer (2009: 111) asserts, "Good governance is not possible without the full cooperation of the governed"

Salameh's (2001: 91) The Jordanian Novels (1980-1990): A Study And Assessment comments that Munis Arazzaz's novels "portray the real conditions of the Arab world....the world of political oppression, suppression, torture, sustained suffering and restriction of freedom." The weakness of Muslims today shows the selfishness of Arab authoritarians in maintaining the Arabs as weak and fragmented. The implementation of western nationalism and the ignorance of the Islamic ideology have led the Muslim world especially Arabs in a fragmented and weak State. "The position of Muslims in the world today is not very elating. Economically they are weak and venerable, politically they stand divided, and morally they as a community are usually off the right path" (Zubair 2003:60). Arazzaz appear to foreshadow this truth through his protagonist Enad's failure in accomplishing his mission. Enad, Dr. Murad and Hassanin realise that they are unable to defend the Arab authoritarians, as well as accomplish their mission and dream of uniting the Arabs. and the flaw in such a mission lies in their inability to go beyond the limitations of ethnicity as an Arab and never looking at the Muslim identity.

Immorality and sins are forbidden in Islam, haram, and extremely prohibited. When they become widely spread in a Muslim community, it indicates a big lost and weakness of Muslims as one nation. For Muslims to be one nation and strong as how the prophet Muhammad (peace and blessing be upon him) has formed, the Ummah should obey Allah and be obedient followers. Historically, "the Muslim power or the Ummah was so strong and expanded to the whole world up to the Ottoman Empire in early Islam. That power of the Muslim Ummah is due to the unity between them". (Al-Ahasan 1993: 23). That strength is shown by one way. The Quran's opening verse in its longest chapter, "The Cow," which proclaims that "This is the Book; in it is guidance for sure, without doubt, to those who fear Allah" (Al-Quran 2: 2). Muslims must be driven by a strong sense of God consciousness or Taqwa. Otherwise, Muslims can never get along with each other.

As a result, the Muslim community has only one way to become united and strong. That is to be loyal to Allah and follow his Shariah. Thus, the unity of the global Muslim community is 
extremely essential. According to Barsie (2003: 241): "There are multiple Quranic verses and prophetic sayings (hadith) that directly urge Muslims to unite and avoid divisions." It is stated in the Quran, "And hold fast to the rope of Allah, and do not be divided among yourselves" (AlQuran 3: 103). The Muslim Ummah should be one united Ummah not divided as how it is today. Khan (2002) presents a clear picture of the word Ummah as he explains: "The Quran and Hadith State clearly that all Muslims from any part of the world form one Ummah or Hizb, community or party, not various geographical entities or nation. They are unified in an indivisible religious communion with no possibility of internal divisiveness or of multiplicity of identity" (Israr 2002: 27).

The discourse of identity representation has to be more comprehensive to include different aspects of individual formation in nation-building. In the case of Arab, identity formation cannot be settled with simple terms like Jordanian, Lebanese, Saudi, Omanis or any other Arab State. The exact and true meaning of Arab identity can be portrayed as unity only when the identity representation, as can be seen in literary discourse, is based on ethnic recognition that create a sense of belonging to the entire Arab community.

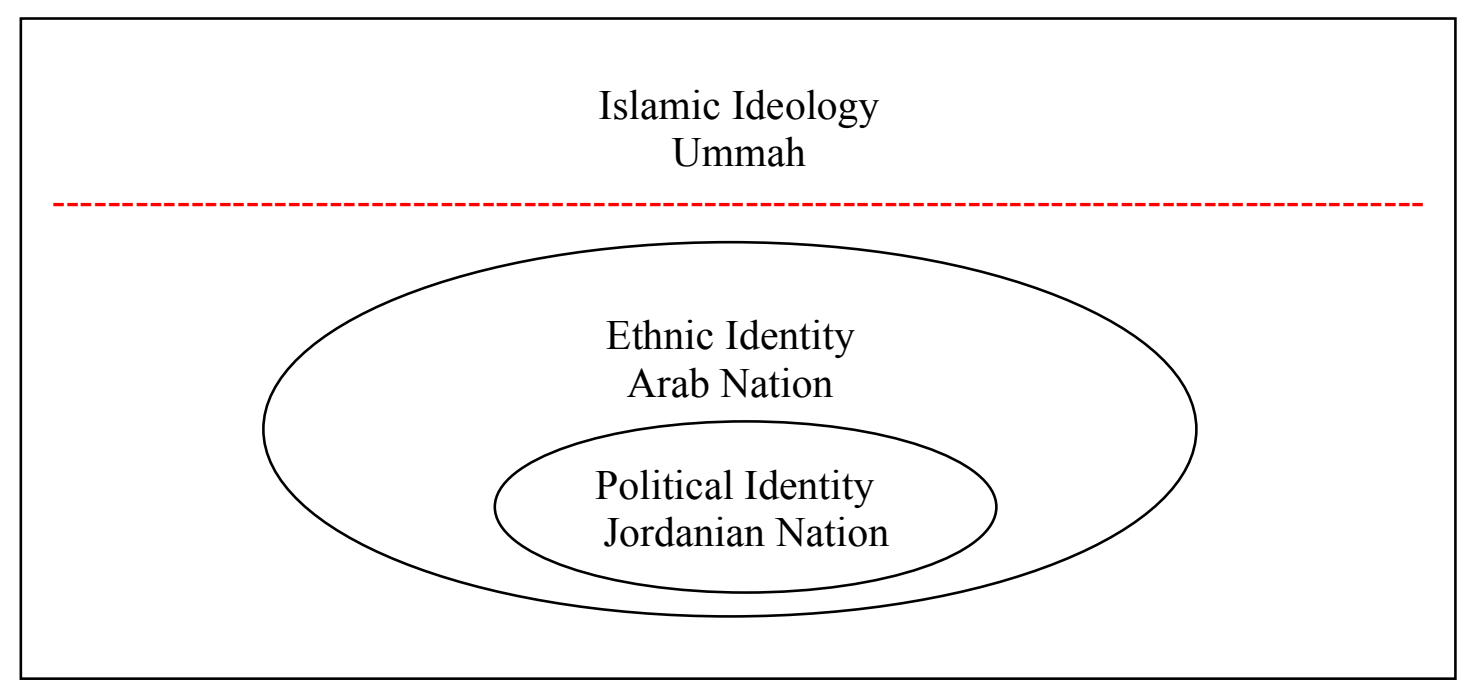

Figure 7.1 The Identity-Intersectional Spaces

Figure 7.1 shows the adoption of identity to each other. The narrowest identity is the political identity which cannot adopt or include more than its own elements such as loyalty to State, flag and the country domination and power, as presented earlier. The second identity is the ethnic identity which includes the first identity 'political' but could not expand to the bigger identity such as the Islamic identity or Islamic identity. The third identity is the only concrete Muslim identity, Islamic identity, which is being marginalised and decayed.

The context of the intersections of identity spaces as illustrated above presents the most significant crisis in the narratives of Arazzaz. The novelist, Arazzaz, feels the torment of divided Arab nations. His novels are nothing more than the struggle that he went through and the pain that he experienced although it was easier for him to shut his eyes and ignore it. Nevertheless, he strived for an Arab nation. However, looking through the Arab spring as political reform shows it is still in a dilemma given the lack of unified Ummatic mindset. The 2010 Arab spring, indeed, is long suffering due to dictatorial regimes, which to a large extent was foreshadowed in Arazzaz's three novels. The novelist depicts the restless efforts of the three protagonists working towards achieving an Arab nation. In the evolutionary sense, the characters in the 
narratives are divided into nations. Some were able to abandon the feeling and the attachment towards political identity as a steppingstone in achieving one united Arab nation, Qawmeyya, as well as indicating to the Islamic identity, or Islameyya.

The focus of this paper is to problematise the absence of the Arab Ummah as seen in the fiction of Arazzaz. However, what we are facing today is something that is not only encountered by the Arabs rather it is a global crisis of Muslim. The selected novels have disregarded the Islamic identity. Therefore, the crisis can no longer be underestimated as we are collectively facing the crisis that is unparalleled to any other crisis. So, it is not an Arab identity that is in crisis, rather it's the entire 'Ummah'. As Osman Baker (2011) aptly states, identity crisis is not only a challenge encountered by Arabs but also to 'Ummah' as it has been with us for a considerable period of time. In the novel discussed, the hope of having one Arab nation as expressed by Enad in Alive In The Death Sea, or Dr. Murad in Confessions Of Silencer only depicts the crisis of fragmented Arab nations. It does not include the identity crisis of Ummah' today. Moreover, Dr. Murad in Confessions Of Silencer narrates his story and sacrifice towards Arab nations. In this novel, Muslim identity as a global identity is excluded. Similarly, Hassanin in The Maze Of Bedouins In The Mirage Scrappers suffers his life under the political identity, recalls for the Arab identity as Qawmeyya but never perceive the Islamic identity as main identity to fight for.

\section{CONCLUSION}

The novels do not include religion as a marker of identity, thus creating a schism in the mind of the Arabs. Therefore, one may argue that identity crisis as experienced by the cahracters has its locus in the lack of Taqwa or God consciousness. This could be another limitation in the narratives of Arazzaz as he appears to disregard the fundamental feature of an Arab identity. Identity crisis embraces larger concerns of social, cultural and political. It is reflected in all protagonists' dream of one Arab nation. Their life journey testified to the exclusion of faith as identity. Thus, their understanding of identity goes well with Arab identity only. Since identity especially the Muslim identity is inflicted with the crisis, the term identity crisis needs to be used and explained in broader sense. There is no excuse to ignore faith in the identity crisis analysis. Political identity limits us to the extent we cannot exercise our freedom in a nation. It just teaches us how to live within certain territory, whom to vote and which rules to obey. Arab has been plagued for decades with political dissent due to the identity which is formed based on fragile nations. Based on the three novels, the Arabs in the narration feel that having one nation is unquestionable yet they are predominantly and unconsciously attach to ideology call 'political identity'. The evolution of Arab, as seen from the identity lens teaches us that, present generations of Arab are more profound with utterances of state based identity. As an example, an individual may say, "I am Jordanian, Palestinian, Syrian and Egyptian than I am an Arab". From this illustration, it is almost unthinkable to move forward champion for an Arab identity. However, a larger issue that this leads to is if we failed to achieve one united Arab, how could we dream for Islamic ideology of 'Ummah'?

\section{References}

Abbas T. 2005. British Muslim: Under Pressure Communities. London: Zeb Books Ltd.

Abdalla, I. A. and Al-Homoud, M. A. 2001. Exploring the Implicit Leadership Theory in the Arabian Gulf States. Applied Psychology:An International Review, (50): 4. pp 506-531

Abdel-Malek, E. 1997.Alive in the Dead Sea. Amman: Ministry of Culture.

AbdRauf, M. 1991. Ummah: the Muslim nation. Kuala Lumpur: DewanBahasa Dan Pustaka.

Ahmed, S \& Abidkarim. 1992. The Roots of Nationalism in the Muslim World. Walnut: Islamic Cultural Workshop.

Alhabashneh, Q. 2008. AlghaebAlmahki: Derasah fe adab Munis Arazzaz As-Seyasi. Amman: Amanat Amman Alkubra. 


\section{Al-Quran}

Al-Ahsan, A. 1993.Ummah or Nation?: Identity Crisis in Contemporary Muslim Society. Intellectual Discourse (1) 1: 94-96.

Al-Ahsan, A. 2003.Muslim world and the international political system in the 21st century. International conference on Muslim unity in the 21st century: opportunities and challenges. Kuala Lumpur.

Alkouri A, Raihanah M.M. \&Hashim R. 2014. Arab National Identity Crisis: Political Strategies and The National Unity Conflict in Munis Arazzaz's Alive In The Dead Sea. Arab World English Journal. (5)1: 304-315.

Anderson, B. 1991. Imagined Communities: Reflections on the Origin and Spread of Nationalism, Rev. and extended ed. London; New York: Verso.

Ashareef, N. 2004. Almagalah assahafeyyah enda Munis Arazzaz. In. In Kalel Ibraheem. (Ed). Aam Ala Arraheel: Sanaweyaht Munis Arazzaz. 187-200 Amman: Ministry Of Culture.

Banks, M. 1996. Ethnicity: Anthropological Constructions. London \& New York: Routledge.

Bellal, A. \& Doswald-Beck, L. 2011. Evaluating the Use of Force during the Arab Spring. Yearbook of International HumanitarianLaw. (14): 3-35

Carmichael, J. 1943. Notes on Arab unity. Foreign Affair (22) 1: 148-153.

Donno, D. \& Russett, B. 2004. Islam, authoritarianism and female empowerment: what are the linkages?.World Politics (56) 4: 582-607.

Gellner, E. 1983. Nations and Nationalism. Ithaca: Cornell University Press.

Halim, B. 1993.The Arab World: Society, Culture, and State. Berkeley, Los Angeles • Oxford: University Of California Press.

Hasan, H. 2010. Alharakat Al-Islamyya Fi Meser. Beirut: Almoassasah Al-Islameyya Le-Nasher.

Khalil, A.A 1992. A new Arab ideology?: the rejuvenation of Arab nationalism. Middle East Journal (46) 1.177

Philips, C. 2013. Everyday Arab identity: Every daily reproduction of the Arab world. USA \& Canada: Routledge.

Philips, H. K. 1996. The Arabs: a short history. Washington: Regnery Publishing, INC.

Sharfuddin, I. M. 1987. Toward an Islamic administrative theory.The American Journal of Islamic Social Sciences. (4) 2: 229-244

Smith, A.D. 1998. Nationalism and Modernism: A Critical Survey of Recent Theories of Nations and Nationalism. London \& New York: Routledge.

Susser, B. 1995. Political ideology in the modern world. Boston, London Toronto Sydney Tokyo Singapore: Allyn and Bacon.

Takriti, A. 2011.Arab youth: don't lose momentum now. The Guardian. Friday 18 February 2011.

http://www.guardian.co.uk/commentisfree/2011/feb/18/arab-dreams-revolutionary-heritage (accessed $16 / 3 / 1012)$

Weiss, N. 2011. Assembly, freedom of, international protection.Max Planck Encyclopaedia of Public International Law.www.mprpil.com. Accessed 12/6/2011 